\title{
Interactions between Insulin-like Growth Factor-I (IGF-I) and the Renin-Angiotensin System in Follicular Growth and Ovulation
}

\author{
Yasunori Yoshimura, ${ }^{\star}$ Nobumitsu Aoki, ${ }^{\ddagger}$ Kou Sueoka, ${ }^{\star}$ Toyohiko Miyazaki, ${ }^{\star}$ Naoaki Kuji, ${ }^{*}$ Mamoru Tanaka, \\ and Toshifumi Kobayashi* \\ *Department of Obstetrics and Gynecology, Keio University School of Medicine, Tokyo, Japan 160; and ${ }^{\ddagger}$ Department of Obstetrics and \\ Gynecology, Kyorin University School of Medicine, Tokyo, Japan 181
}

\begin{abstract}
The interactions between insulin-like growth factor-I (IGF-I) and the renin-angiotensin system (RAS) in follicular growth and ovulation were studied with the use of an isolated perfused rabbit ovary preparation. Ovulation failed to occur in either control ovaries or the experimental ovaries perfused with IGF-I in a concentration of 1,10 , or $100 \mathrm{ng} / \mathrm{ml}$ in the absence of gonadotropin. Exposure to IGF-I stimulated the secretion rate of angiotensin II-like immunoreactivity (Ang II-IR) in perfused rabbit ovaries in a dose-dependent manner. The percent increase in follicle diameter in ovaries perfused with IGF-I for $12 \mathrm{~h}$ was significantly correlated with the secretion rate of Ang II-IR at $12 \mathrm{~h}$ after exposure to IGF-I. The addition of IGFBP-3 to the perfusate did not induce ovulation in the absence of gonadotropin, but exposure to IGFBP-3 inhibited hCG-induced ovulation in a dosedependent manner. In addition, IGFBP-3 significantly reduced the ovarian secretion rate of Ang II-IR and prostaglandins stimulated by hCG administration. Intrafollicular plasminogen activator (PA) activity significantly increased within $4 \mathrm{~h}$ after exposure to $100 \mathrm{ng} / \mathrm{ml}$ of IGF-I, compared with that in control ovaries perfused with medium alone. The concomitant addition of IGFBP-3 to the perfusate significantly reduced the IGF-I-stimulated PA activity in the preovulatory follicles at 4, 6, and $8 \mathrm{~h}$ after exposure to IGF-I. However, IGFBP-3 alone affected neither the ovarian secretion rate of Ang II-IR nor intrafollicular PA activity. Exposure to streptokinase, an exogenous PA, in vitro stimulated both follicular growth and the intrafollicular Ang II-IR content. In conclusion, IGF-I enhances both ovarian Ang II production and follicular development by stimulating intrafollicular PA activity. (J. Clin. Invest. 1996. 98:308-316.) Key words: insulin-like growth factor-I • angiotensin II • insulin-like growth factor binding protein $\bullet$ plasminogen activator activity $\bullet$ follicular growth
\end{abstract}

\section{Introduction}

The concept of classical endocrine control of ovarian function has now been extended to a more complex regulatory system,

\footnotetext{
Address correspondence to Yasunori Yoshimura, M.D., Department of Obstetrics and Gynecology, Keio University School of Medicine, 35 Shinanomachi, Shinjuku, Tokyo, Japan 160. Phone: 3-3353-1211; FAX: 3-3352-1598.

Received for publication 27 December 1995 and accepted in revised form 8 May 1996.
}

J. Clin. Invest.

(C) The American Society for Clinical Investigation, Inc.

0021-9738/96/07/0308/09 \$2.00

Volume 98, Number 2, July 1996, 308-316 including paracrine and autocrine modulating mechanisms (1, 2). Among many factors, locally produced intraovarian insulin-like growth factors (IGFs) ${ }^{1}$ and their binding proteins (IGFBPs) and the renin-angiotensin system (RAS) have been shown to play important roles in the control of folliculogenesis and ovulation $(1,3-7)$. IGFs as well as IGFBPs are produced by ovarian granulosa cells $(4,5,8)$. IGF-I acts synergistically with gonadotropins in stimulating a variety of granulosa cell functions, including estrogen and progesterone production and the formation of $\mathrm{LH}$ receptors $(1,9,10)$. Furthermore, rat granulosa cells possess specific IGF type I receptors (10). We previously demonstrated that growth hormone $(\mathrm{GH})$ amplifies gonadotropin actions in the process of follicular development and ovulation, at least in part, stimulating ovarian IGF-I production (11). The biological effects of IGF-I are modulated by a family of IGFBPs in a complex and incompletely understood manner $(5,12-14)$. In the ovary, IGFBP-3 appears to neutralize the actions of gonadotropin and IGF-I, probably via its ability to sequester IGF-I $(12,13,15)$.

A functional local RAS is also known to exist in the ovary $(6,7,16-19)$. The findings of higher follicular concentrations of prorenin, renin and angiotensinogen in humans and the identification of angiotensinogen and renin messenger RNA in the rat ovary support the presence of a local RAS in the ovary (16-19). Pellicer et al. (6) demonstrated that intraperitoneal administration of an angiotensin II (Ang II) receptor antagonist, saralasin, blocked ovulation in immature rats treated with gonadotropins. We also found that Ang II administration at 2 -h intervals induced oocyte maturation and ovulation in in vitro perfused rabbit ovaries in the absence of gonadotropin (20). In addition, the rate of Ang II secretion in perfused rabbit ovaries was enhanced during the ovulatory process by exposure to hCG, and the concomitant addition of saralasin inhibited hCG-induced ovulation in vitro in a dose-dependent manner $(7,20)$. These observations point toward a potentially important role of ovarian RAS in the preovulatory cascade.

Perfusion of isolated rabbit ovaries provides an opportunity to conduct detailed studies of the intact organ under carefully regulated conditions that are independent of systemic influences $(7,11,21)$. Previous in vitro studies $(7,11,20)$ revealed the possible involvement of IGF-I in follicular growth and oocyte maturation and the function of locally produced Ang II as a significant autocrine or paracrine modulator in the process of ovulation. We conducted the present study to investigate interactions between the IGF-I-IGFBP system and the RAS in follicular growth and ovulation.

1. Abbreviations used in this paper: Ang II-IR, angiotensin II-like immunoreactivity; $\mathrm{GH}$, growth hormone; $\mathrm{hCG}$, human chorionic gonadotropin; IGF-I, insulin-like growth factor-I; IGFBP-3, insulin-like growth factor binding protein-3; PA, plasminogen activator; PG, prostaglandin; RAS, renin-angiotensin system. 


\section{Materials and Methods}

Animals. A total of 157 sexually mature female Japanese white rabbits weighing $3.5-4.5 \mathrm{~kg}$ were used in the present study. They were cared for according to the guidelines of Keio University School of Medicine. Rabbits were isolated for a minimum of $3 \mathrm{wk}$ before the experimental procedure and were caged individually and fed water and a diet of Purina rabbit chow ad libitum under controlled light and temperature conditions. The rabbits were anesthetized with intravenous administration of sodium pentobarbital $(32 \mathrm{mg} / \mathrm{kg})$. After heparin sulfate $(120 \mathrm{U} / \mathrm{kg})$ was administered for anticoagulation, laparotomy was performed. Five ovaries were excluded from further study, because they had fewer than three mature follicles, or $50 \%$ or more of the surface follicles were hemorrhagic.

Ovarian perfusion. Although the details of the standard perfusion system have been modified over the years, the basic components have remained constant $(22,23)$. The ovarian artery and vein were cannulated in situ after ligation of the major anastomotic connections, as previously described $(21,22)$. The ovary was removed along with its artery, vein, and supporting adipose tissue and immediately placed in a perfusion chamber. The perfusion fluid consisted of 150 $\mathrm{ml}$ of medium 199 (GIBCO BRL, Gaithersburg, MD) containing 1\% bovine serum albumin (BSA) (Fraction V powder; Sigma Chemical Co., St. Louis, MO), which was supplemented with heparin sulfate, insulin, streptomycin, and penicillin $\mathrm{G}$ and adjusted to a $\mathrm{pH}$ of 7.4. BSA was added to the basic perfusion fluid to increase the oncotic pressure and reduced edema formation. Ovaries were observed every $15 \mathrm{~min}$ throughout the $12 \mathrm{~h}$ of perfusion for evidence of follicle growth and rupture. At the time of follicle rupture, the ovulated ovum surrounded by its cumulus mass was recovered carefully from the ovarian surface with a Pasteur pipette. The time interval between human chorionic gonadotropin (hCG) administration and follicle rupture was recorded. The ovulatory efficiency (percent of follicles $>1.5$ $\mathrm{mm}$ that ovulated) was calculated for each group.

Biochemical materials. Recombinant human IGF-I was purchased from Amersham International (Amersham, UK). Nonglycosylated recombinant human IGFBP-3 was kindly provided by Dr. C. A. Maack (Cletrix Pharmaceuticals, Inc., Santa Clara, CA). Synthetic Ang II was purchased from Sigma Chemical Co. ${ }^{125}$ I-Ang II $(2,200 \mathrm{Ci} /$ mmol) was obtained from New England Nuclear (Boston, MA).

Experimental design. The first experiment using 18 rabbits was undertaken to determine whether the addition of IGF-I to the perfusate stimulates the production of Ang II-like immunoreactivity (Ang II-IR) in perfused rabbit ovaries. The serum levels of IGF-I in rabbits ranged from 10 to $20 \mathrm{ng} / \mathrm{ml}$ and did not show any significant changes during the preovulatory process. Accordingly, one ovary from each rabbit was perfused with recombinant human IGF-I in a concentration of 1,10 , or $10^{2} \mathrm{ng} / \mathrm{ml}$. The contralateral ovary was simultaneously placed in a separate chamber containing medium alone to serve as a control. Six ovaries were treated with each dose of IGF-I. Ovarian perfusion was carried out for $12 \mathrm{~h}$ after administration of IGF-I. In ovaries perfused with $10^{2} \mathrm{ng} / \mathrm{ml}$ of IGF-I, the concentration of IGF-I in the perfusate ranged from 70 to $80 \mathrm{ng} / \mathrm{ml} 12 \mathrm{~h}$ after perfusion. Follicles with a diameter greater than $1.2 \mathrm{~mm}$ were measured at the onset of perfusion using a pair of slide calipers (Mitsutomo Co., Tokyo, Japan). The mean number of mature follicles per ovary was $5.24 \pm 0.28$ (range, 4-7). The follicle diameter of the ovary before perfusion was defined as $100 \%$. The follicle diameter was also determined at $12 \mathrm{~h}$ after the onset of perfusion, and the percent increase for each follicle was calculated. Both arterial and venous samples were obtained before perfusion and $1,2,4,6,8$, and $12 \mathrm{~h}$ after perfusion to determine the ovarian secretion rate of Ang II-IR. The perfusate was introduced through the ovarian artery cannula and was collected from the cannulated vein and recycled. The arterial samples were taken from the apparatus at a site just before perfusate entered the cannulated ovarian artery, while the venous samples were collected from effluent through the cannulated vein. The ovarian secretion rate of Ang II-IR was calculated by determining the difference in concentrations of
Ang II-IR between the venous and arterial samples, as described previously (21). Samples were stored at $-80^{\circ} \mathrm{C}$ until the concentrations of Ang II-IR were determined.

In the second experiment to determine the effects of IGFBP-3 on hCG-induced ovulation and production of Ang II-IR, one ovary was perfused with IGFBP-3 in a concentration of $1,10,10^{2}$, or $10^{3} \mathrm{ng} / \mathrm{ml}$. The contralateral ovary of each rabbit was simultaneously placed in a separate chamber with medium alone and served as a control. $30 \mathrm{~min}$ after the onset of perfusion, $50 \mathrm{IU}$ of hCG (CH-446, biological activity $3,830 \mathrm{IU} / \mathrm{mg}$; Organon, Oss, The Netherlands) was added to the perfusate of both ovaries. Ovaries were perfused for $12 \mathrm{~h}$ after hCG administration. Six ovaries were treated with each dose of IGFBP-3. In another group of six rabbits, one ovary was perfused with $10^{3} \mathrm{ng} / \mathrm{ml}$ of IGFBP-3 and the contralateral ovary was perfused with medium alone. Ovarian perfusion was performed for $12 \mathrm{~h}$ after administration of IGFBP-3. Both arterial and venous samples were obtained before the administration of hCG and 1, 2, 4, 6, 8, and $12 \mathrm{~h}$ thereafter to determine the ovarian secretion rates of Ang II-IR and prostaglandins (PGs). Samples were stored at $-80^{\circ} \mathrm{C}$ until the concentrations of Ang II-IR and PGs were determined.

The third experiment using six rabbits was undertaken to determine whether Ang II reverses the inhibitory effects of IGFBP-3 on hCG-induced PG production and ovulation in perfused rabbit ovaries. Both ovaries were perfused with $10^{3} \mathrm{ng} / \mathrm{ml}$ of IGFBP-3. $30 \mathrm{~min}$ after the onset of perfusion, $50 \mathrm{IU}$ of hCG was added to the perfusate of both ovaries. Ang II was dissolved in PBS (GIBCO BRL) at a concentration of $1.0 \mathrm{mg} / \mathrm{ml}$. The solution $(100 \mu \mathrm{g})$ was administered as a bolus injection of one ovary every $2 \mathrm{~h}$ for $12 \mathrm{~h}$ of perfusion $(7,20)$, while $0.1 \mathrm{ml}$ of PBS was administered every $2 \mathrm{~h}$ in the contralateral ovary. Both arterial and venous samples were obtained before the administration of hCG and 1, 2, 4, 6, 8, and $12 \mathrm{~h}$ thereafter to determine the secretion rate of PGs. Samples were stored at $-80^{\circ} \mathrm{C}$ until the concentrations of PGs were determined.

The fourth experiment using 72 rabbits was conducted to assess the effect of IGFBP-3 on IGF-I-stimulated plasminogen activator (PA) activity in the preovulatory follicles. Ovaries were perfused with medium alone, $10^{2} \mathrm{ng} / \mathrm{ml}$ of IGFBP- $3,10^{2} \mathrm{ng} / \mathrm{ml}$ of IGF-I, or $10^{2} \mathrm{ng} / \mathrm{ml}$ of IGF-I plus $10^{2} \mathrm{ng} / \mathrm{ml}$ of IGFBP-3. Ovarian perfusion was terminated before and 2, 4, 6, 8, and $12 \mathrm{~h}$ after IGF-I administration. At least three ovaries from three different rabbits were examined at each interval. Mature follicles were excised immediately at each time of the perfusion and stored at $-80^{\circ} \mathrm{C}$ until intrafollicular PA activity was determined.

The final experiment using 26 rabbits was undertaken to determine whether streptokinase, an exogenous plasminogen activator, stimulates follicular growth and intrafollicular Ang II-IR content of perfused rabbit ovaries in the absence of gonadotropin. Ovaries were perfused with $100 \mathrm{U}$ of streptokinase (Sigma Chemical Co.). At least six ovaries from six different rabbits were examined at each interval. The diameter of follicles greater than $1.2 \mathrm{~mm}$ was measured at the onset of perfusion. The mean number of mature follicles per ovary was $5.68 \pm 0.36$ (range, $4-8$ ). The first ovulation in this system occurred at 6 to $8 \mathrm{~h}$ after exposure to $100 \mathrm{U}$ of streptokinase (24). Therefore, ovarian perfusion was terminated before and $2,4,6$, and $8 \mathrm{~h}$ after exposure to streptokinase. In another group of six rabbits, one ovary was perfused with $100 \mathrm{U}$ of streptokinase. The contralateral ovary was perfused with $100 \mathrm{U}$ of streptokinase plus $10^{3} \mathrm{ng} / \mathrm{ml}$ of IGFBP-3. Ovarian perfusion was performed for $6 \mathrm{~h}$ after streptokinase administration. The follicle diameter was determined at each duration of perfusion and the percent increase was calculated for each follicle. Mature follicles were immediately excised and stored at $-80^{\circ} \mathrm{C}$ until the intrafollicular Ang II-like immunoreactivity content was determined.

Measurement of Ang II-like immunoreactivity in follicles and perfusates. Perfused rabbit ovaries were removed at each time during the perfusion and placed in ice-cold physiological saline. Mature follicles were isolated under a dissecting microscope. Four to eight follicles were placed in $1 \mathrm{ml}$ of ice-cold $20 \mathrm{mM}$ sodium phosphate buffer containing 10,000 IU/ml of aprotinin (Sigma Chemical Co.), homoge- 


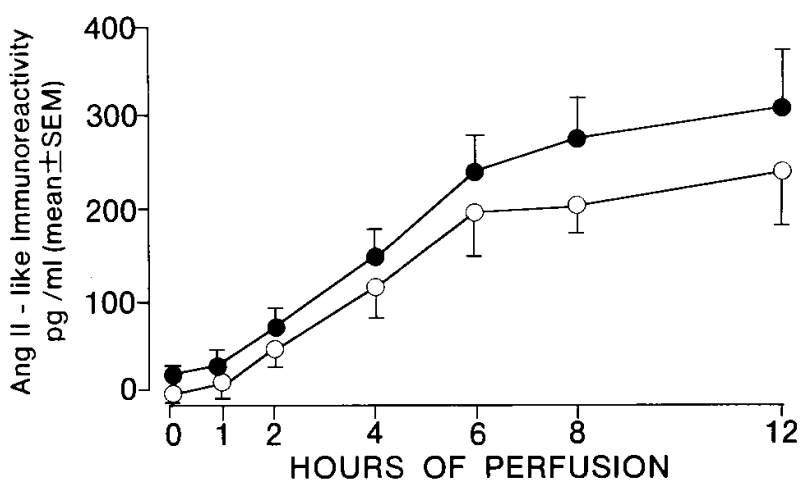

Figure 1. Changes in concentrations of Ang II-IR in arterial and venous samples. Rabbit ovaries were perfused with IGF-I in a concentration of $10^{2} \mathrm{ng} / \mathrm{ml}$. The arterial samples $(\bigcirc)$ were taken from the apparatus at a site just before perfusate entered the cannulated ovarian artery, while the venous samples $(\bullet)$ were collected from effluent through the cannulated vein. Data points are the mean \pm SEM of at least six ovaries from six different rabbits.

nized with a Bio-Mixer (Kenis Scientific Institute, Tokyo, Japan), and then centrifuged at $15,000 \mathrm{~g}$ for $30 \mathrm{~min}$ at $4^{\circ} \mathrm{C}$. Ang II-IR was extracted using the method described by Beadwell (25) with minor modifications. After ${ }^{125} \mathrm{I}$-Ang II was added to estimate the recovery rate, the supernatants and perfusate samples $(0.1 \sim 0.6 \mathrm{ml})$ were suspended in $30 \mathrm{mg}$ of florisil to absorb Ang II-IR in the samples. The mixtures were centrifuged at $400 \mathrm{~g}$ for $10 \mathrm{~min}$ and washed twice with $1 \mathrm{ml}$ of distilled water. The precipitates were eluted twice with $0.5 \mathrm{~N}$ hydrochloric-acetone solution and centrifuged at $400 \mathrm{~g}$ for $5 \mathrm{~min} .1 \mathrm{ml}$ of petroleum ether was added to the supernatant to separate unsubstituted fatty acids. The aqueous extract were evaporated under a stream of nitrogen gas. The extracts containing Ang II-IR were reconstituted in $500 \mu \mathrm{l}$ of $0.05 \mathrm{M}$ borate buffer ( $\mathrm{pH} 8.5$ ) containing $1.2 \%$ BSA $0.5 \% \mathrm{NaCl}$, and $0.1 \%$ EDTA-2Na. Aliquots of these extracts were used for RIA of Ang II-IR and determination of recovery rates. The average recovery rate for Ang II-IR was $89.5 \%$. The Ang II-IR in the tissue extract and perfusate was examined by RIA using ${ }^{125}$ I-Ang II purchased from New England Nuclear Co. (Boston, MA) and rabbit antiserum against an Ang II-BSA conjugate (26). The antiserum cross-reacted as follows: $0.3 \%$ with angiotensin I, $10^{-4} \%$ with [Sar ${ }^{1}$-Ala ${ }^{8}$ ]Ang II, 30.8\% with angiotensin III, $46.0 \%$ with des-[ $\mathrm{Arg}^{1}$, $\left.\mathrm{Asp}^{2}\right]$ Ang II, and $100 \%$ with [ $\left.\mathrm{Val}^{5}\right]$ Ang II. The standard curve for this assay ranged from $0.75 \sim 500 \mathrm{pg} /$ tube. The intra-assay and interassay coefficients of variation for Ang II-IR were 11.7 and $12.9 \%$, respectively.

Measurement of prostaglandin. PG was extracted as previously described (27). The average recovery rates of $\mathrm{PGF}_{2 \alpha}$ and $\mathrm{PGE}_{2}$ were 79.4 and $84.8 \%$. The concentrations of $\mathrm{PGF}_{2 \alpha}$ and $\mathrm{PGE}_{2}$ were measured by RIA kits supplied by Amersham International Plc (Amersham Corp, UK). Prostaglandin $\mathrm{F}_{2 \alpha}$ and $\mathrm{PGE}_{2}$ antibodies crossreacted $2 \%$ with other closely related PGs. Intra-assay and interassay coefficients of variation were 8.2 and $9.8 \%$, respectively, for $\mathrm{PGF}_{2 \alpha}$, and 7.6 and $9.2 \%$, respectively, for $\mathrm{PGE}_{2}$. The sensitivities of the assay for $\mathrm{PGF}_{2 \alpha}$ and $\mathrm{PGE}_{2}$ were 3 and $43 \mathrm{pg} /$ tube, respectively.

Measurement of $P A$ activity in follicles. Intrafollicular PA activity was determined using a Spectrolyse tissue PA (t-PA) activity assay kit produced by American Diagnostic, Inc. (New York, NY), as described previously (28). Briefly, the preovulatory follicles were excised, minced, and homogenized in $0.1 \mathrm{M}$ Tris- $\mathrm{HCl}$ buffer ( $4 \mathrm{vol})$ and $0.5 \mathrm{M}$ potassium thiocyanate $(1 \mathrm{vol})$ at $\mathrm{pH} 7.4$ in a homogenizer. The homogenate was centrifuged at $2,900 \mathrm{~g}$ at $4^{\circ} \mathrm{C}$ for $20 \mathrm{~min}$ and the supernatant was used in the assay. This assay is based on the functional parabolic rate assay. Fibrinolytic activity, expressed in IU, was determined using a human melanoma PA reference standard (Lot 831517 of the NIBSC, London, UK). The standard curve for PA ranged from

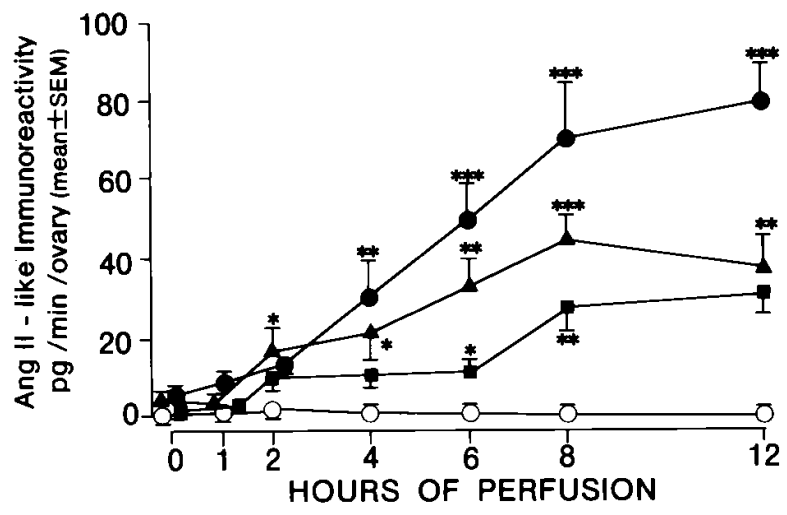

Figure 2. Effects of IGF-I on secretion rates of Ang II-IR by perfused rabbit ovaries. Rabbit ovaries were perfused with medium alone $(\bigcirc)$, or with IGF-I in a concentration of $1 \mathrm{ng} / \mathrm{ml}(\mathbb{\square}), 10 \mathrm{ng} / \mathrm{ml}$ $(\boldsymbol{\Delta})$, or $10^{2} \mathrm{ng} / \mathrm{ml}(\bullet)$. Ovarian secretion rate (pg/min/ovary) was calculated by determining the difference in concentrations of Ang II-IR between venous and arterial samples. Data points are the mean \pm SEM of at least six ovaries from six different rabbits. Values with asterisks differed significantly from values in ovaries perfused with medium alone; ${ }^{*} P<0.05,{ }^{* *} P<0.01 ; * * * P<0.001$.

0.2 to $3.0 \mathrm{IU} / \mathrm{ml}$. The intra-assay and interassay coefficients of variation were 6.9 and $8.4 \%$, respectively.

Statistical analysis. Data are presented as the mean \pm SEM. Normal distribution of data on the percent increase in follicle diameters and ovulatory efficiency was obtained by arcsine transformation and assessed using analysis of variance. Differences in PA activity in follicular tissues and in concentrations of Ang II-IR and PGs among the treatment groups during perfusion were assessed by two-way analysis of variance, with the two independent variables being time of perfusion and treatment group. This analysis was followed by Scheffé's test to determine the difference between two groups. The correlation between follicular growth and the secretion rate of Ang II-IR was also evaluated by analysis of variance. A regression line was estimated using the least-squares method of curve fitting. Differences were considered statistically significant if the $P$ value was $<0.05$.

\section{Results}

In the first experiment, ovulation failed to occur in either the control ovaries or the experimental ovaries treated with IGF-I in a concentration of 1,10 , or $10^{2} \mathrm{ng} / \mathrm{ml}$ in the absence of gonadotropin. The concentrations of Ang II-IR in arterial and venous samples increased gradually by IGF-I administration (Fig. 1). We found previously that exogenously administered Ang II decreased as the increasing duration of ovarian perfusion, suggesting that Ang II could be metabolized in the perfused rabbit ovaries (20). In the subsequent experiment, therefore, the ovarian secretion rate of Ang II-IR in the in vitro perfused rabbit ovaries was determined. The secretion rate of Ang II-IR, which was calculated by determining the difference in concentrations of Ang II-IR between the venous and arterial samples, was very low in the unstimulated control ovaries during the entire perfusion period (Fig. 2). Exposure to IGF-I in a concentration of 10 or $10^{2} \mathrm{ng} / \mathrm{ml}$ significantly enhanced the secretion rate of Ang II-IR in perfused rabbit ovaries within 2 to $4 \mathrm{~h}$. In addition, IGF-I stimulated the secretion of Ang II-IR in perfused rabbit ovaries in a dose-dependent manner. The relationship between follicular growth and the secretion rate of Ang II-IR in rabbit ovaries perfused with different concentrations of IGF-I is shown in Fig. 3. The percent in- 


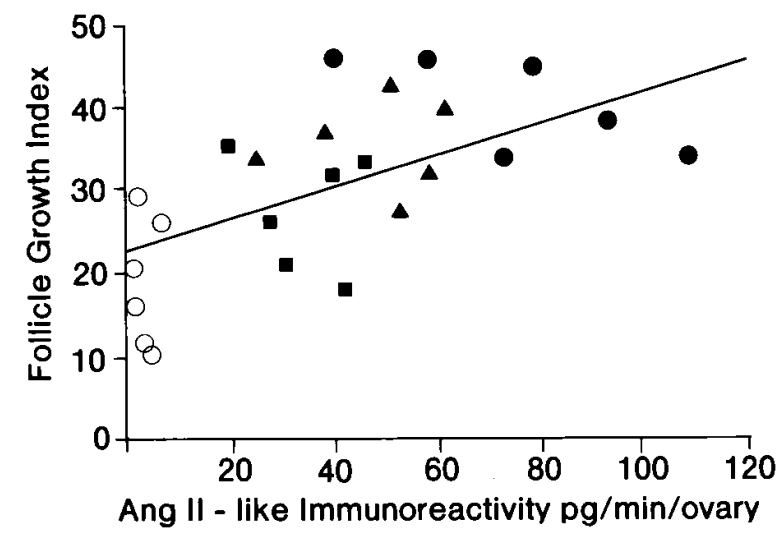

Figure 3. Relationship between follicular growth and the secretion rate of Ang II-IR in perfused rabbit ovaries. Ovaries were perfused with medium alone $(\bigcirc)$, or with IGF-I in a concentration of $1 \mathrm{ng} / \mathrm{ml}$ $(\boldsymbol{\square}), 10 \mathrm{ng} / \mathrm{ml}(\boldsymbol{\Lambda})$, or $10^{2} \mathrm{ng} / \mathrm{ml}(\bullet)$. Six ovaries from six different rabbits were used in each treatment group. Ovarian secretion rate of Ang II-IR was calculated by determining the difference in concentrations of Ang II-IR between venous and arterial samples at $12 \mathrm{~h}$ after IGF-I administration. The diameter of each follicle was measured at the onset of perfusion and $12 \mathrm{~h}$ later, and the percent increase in each follicle was determined. Data on the mean percent increase in mature follicles in one ovary were subjected to arcsine transformation (follicle growth index). A significant correlation between the percent increase in follicle diameter and the secretion rate of Ang II-IR was noted $(\mathrm{r}=0.6285, P<0.005)$.

crease in follicle diameter in ovaries perfused with IGF-I for $12 \mathrm{~h}$ was significantly correlated with the secretion rate of Ang II-IR at $12 \mathrm{~h}$ after exposure to IGF-I.

Treatment with 50 IU of hCG induced ovulation in vitro in all ovaries perfused with medium alone, or with 1 or $10 \mathrm{ng} / \mathrm{ml}$ of IGFBP-3, whereas two of six ovaries treated with hCG plus $10^{2}$ or $10^{3} \mathrm{ng} / \mathrm{ml}$ of IGFBP-3 failed to ovulate (Table I). Ovulation did not occur in ovaries perfused with either medium alone or $10^{3} \mathrm{ng} / \mathrm{ml}$ of IGFBP-3 in the absence of gonadotropin. The mean number of ovulations per ovary was significantly lower in ovaries perfused with $10,10^{2}$ or $10^{3} \mathrm{ng} / \mathrm{ml}$ of IGFBP-3 than in hCG-treated controls. The time of ovulation did not differ significantly among any of the treatment groups. Exposure to IGFBP-3 inhibited hCG-induced ovulation in a dose-dependent manner (Fig. 4).

The secretion rate of Ang II-IR significantly increased within $1 \mathrm{~h}$ after exposure to hCG, reaching its maximum at $6 \mathrm{~h}$

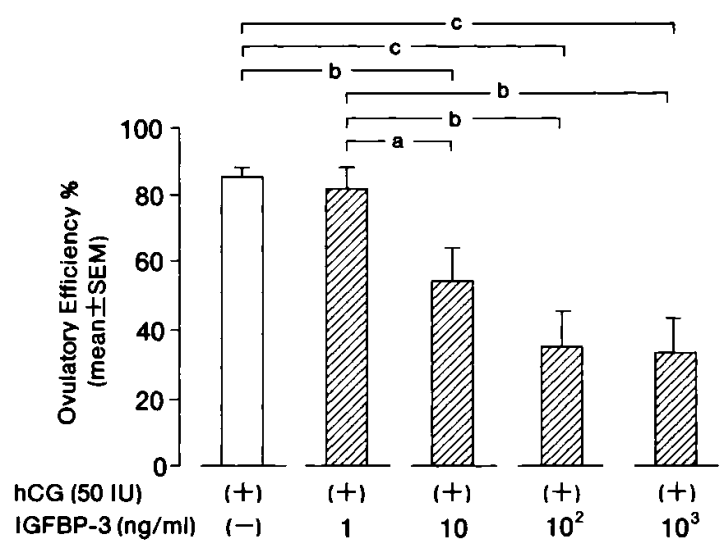

Figure 4. Effect of IGFBP-3 on hCG-induced ovulation. Ovaries were perfused with medium alone or with IGFBP-3 in a concentration of $1,10,10^{2}$ or $10^{3} \mathrm{ng} / \mathrm{ml} .30 \mathrm{~min}$ after the onset of perfusion, 50 IU of hCG was added to the perfusate. Ovulatory efficiency was defined as the percentage of mature follicles that proceeded to rupture during $12 \mathrm{~h}$ of perfusion. Data represent the mean \pm SEM of six ovaries from six different rabbits. $a, P<0.05 ; b, P<0.01 ; c, P<0.001$ ).

and declining thereafter (Figs. 2 and 5). The concomitant addition of IGFBP-3 to the perfusate significantly reduced the ovarian secretion rate of Ang II-IR stimulated by hCG administration at 4 and $6 \mathrm{~h}$ (Fig. 5). In the absence of hCG, however, IGFBP-3 alone did not affect the ovarian secretion of Ang IIIR. The secretion rates of $\mathrm{PGE}_{2}$ and $\mathrm{PGF}_{2 \alpha}$ in ovaries perfused with medium alone remained low throughout the 12-h perfusion period (Fig. 6). There was no significant difference in the ovarian secretion rates of $\mathrm{PGE}_{2}$ and $\mathrm{PGF}_{2 \alpha}$ between ovaries perfused with medium alone and with IGFBP-3. Exposure to hCG significantly increased the production of $\mathrm{PGE}_{2}$ at 4, 6, 8, and $12 \mathrm{~h}$, and of $\mathrm{PGF}_{2 \alpha}$ at 6,8 , and $12 \mathrm{~h}$, compared with that in ovaries perfused with medium alone. The concomitant addition of IGFBP-3 to the perfusate significantly reduced the hCG-stimulated ovarian secretion rates of $\mathrm{PGE}_{2}$ and $\mathrm{PGF}_{2 \alpha}$.

The addition of Ang II in the perfusate at 2-h intervals reversed the inhibitory effect of IGFBP-3 on hCG-induced ovulation (Table II). The ovulatory efficiency in hCG-treated ovaries perfused with IGFBP-3 plus Ang II did not differ significantly from that in ovaries treated with hCG alone (Fig. 4). The time of ovulation in hCG-treated ovaries perfused with IGFBP-3 alone and with IGFBP-3 plus Ang II did not differ significantly. Additionally, Ang II significantly stimulated the

Table I. Effects of IGFBP-3 on hCG-induced Ovulation

\begin{tabular}{|c|c|c|c|c|c|c|c|}
\hline & \multirow[b]{2}{*}{$\begin{array}{c}\mathrm{hCG} \\
(50 \mathrm{IU})\end{array}$} & \multicolumn{4}{|c|}{ hCG $(50 \mathrm{IU})+$ IGFBP-3 } & \multirow[b]{2}{*}{$\begin{array}{c}\text { IGFBP-3 } \\
\left(10^{3} \mathrm{ng} / \mathrm{ml}\right)\end{array}$} & \multirow[b]{2}{*}{$\begin{array}{l}\text { Medium } \\
\text { alone }\end{array}$} \\
\hline & & $1 \mathrm{ng} / \mathrm{ml}$ & $10 \mathrm{ng} / \mathrm{ml}$ & $10^{2} \mathrm{ng} / \mathrm{ml}$ & $10^{3} \mathrm{ng} / \mathrm{ml}$ & & \\
\hline No. of ovaries ovulated & 24 & 6 & 6 & 6 & 6 & 6 & 6 \\
\hline No. of ovaries ovulating & 24 & 6 & 6 & 4 & 4 & 0 & 0 \\
\hline No. of ovulations per ovary* & $5.12 \pm 0.21$ & $4.83 \pm 0.49$ & $3.83 \pm 0.54^{\ddagger}$ & $2.39 \pm 0.48^{\S}$ & $2.20 \pm 0.62^{\S}$ & 0 & 0 \\
\hline Time of ovulation $(\mathrm{h}) *$ & $9.27 \pm 0.49$ & $8.63 \pm 0.36$ & $9.01 \pm 0.24$ & $8.53 \pm 0.78$ & $8.78 \pm 0.56$ & & \\
\hline
\end{tabular}

* Mean \pm SEM. ${ }^{*}$ Significantly $(P<0.01)$ compared with hCG-treated ovaries. ${ }^{\S}$ Significantly $(P<0.001)$ compared with hCG-treated ovaries. 


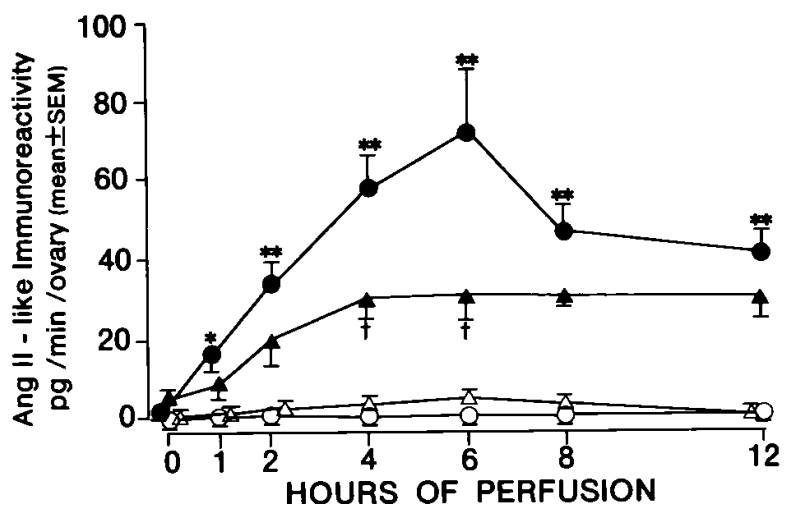

Figure 5. Effect of IGFBP-3 on hCG-stimulated secretion rate of Ang II production in perfused rabbit ovaries. Ovaries were perfused with medium alone $(\bigcirc), 10^{2} \mathrm{ng} / \mathrm{ml}$ of IGFBP-3 alone $(\triangle), 50 \mathrm{IU}$ of hCG alone $(\bullet)$, or 50 IU of hCG plus $10^{2} \mathrm{ng} / \mathrm{ml}$ of IGFBP-3 $(\boldsymbol{\Delta})$. Ovarian secretion rate of Ang II-IR was calculated by determining the difference in concentrations of Ang-II-IR between venous and arterial samples. Data points represent the mean \pm SEM of six ovaries from six different rabbits. Values with asterisks differed significantly from values in ovaries perfused with medium alone; $* P<0.05 ; * * P<$ $0.01 ; * * * P<0.001$. Values with daggers differed significantly from values in hCG-treated ovaries; ${ }^{\dagger} P<0.05$.

secretion rates of $\mathrm{PGE}_{2}$ and $\mathrm{PGF}_{2 \alpha}$ in ovaries perfused with hCG plus IGFBP-3 within 2 to $4 \mathrm{~h}$ (Fig. 7). The reduction in PG production by IGFBP-3 was completely blocked by the concomitant addition of Ang II.

Intrafollicular PA activity in ovaries perfused with medium alone or IGFBP-3 alone remained low throughout the 12-h perfusion period (Fig. 8). PA activity increased significantly within $4 \mathrm{~h}$ after exposure to $10^{2} \mathrm{ng} / \mathrm{ml}$ of IGF-I, compared with that in control ovaries perfused with medium alone. The intrafollicular PA activity reached maximal levels at $6 \mathrm{~h}$ after exposure to IGF-I and declined gradually thereafter, returning to levels similar to those in controls by $12 \mathrm{~h}$. Concomitant addition of IGFBP-3 to the perfusate significantly reduced IGFI-stimulated PA activity in the preovulatory follicles at 4, 6, and $8 \mathrm{~h}$ after exposure to IGF-I.

Exposure to streptokinase in vitro stimulated both follicular growth and the intrafollicular Ang II-IR content in perfused rabbit ovaries (Fig. 9). The Ang II-IR content significantly increased at 4, 6, and $8 \mathrm{~h}$ after streptokinase administration. The follicle diameter increased in streptokinase-treated ovaries as the intrafollicular content of Ang II-IR content increased significantly. However, IGFBP-3 affected neither the streptokinase-stimulated Ang II production nor follicular growth (Table III).

\section{Discussion}

Recent studies derived from our laboratory have demonstrated that $\mathrm{GH}$ amplifies gonadotropin actions in the process of follicular development and ovulation by stimulating ovarian IGF-I production (11). In addition, exposure to IGF-I in vitro significantly stimulated follicular growth and the production of estradiol $\left(\mathrm{E}_{2}\right)$ in in vitro perfused rabbit ovaries in the absence of gonadotropin or GH (29). In the present study, the addition of IGF-I to the perfusate significantly stimulated the secretion rate of Ang II-IR in perfused rabbit ovaries. This stimulatory
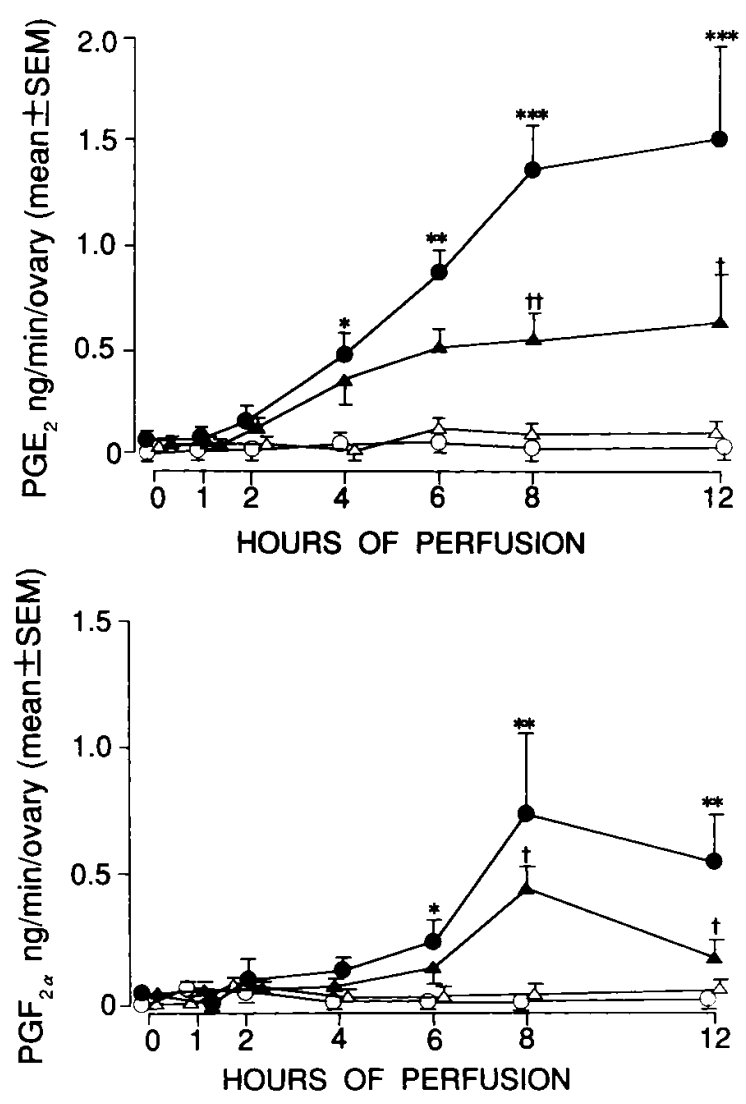

Figure 6. Effect of IGFBP-3 on hCG-induced PG production in perfused rabbit ovaries. Ovaries were perfused with medium alone $(O)$, $10^{2} \mathrm{ng} / \mathrm{ml}$ of IGFBP-3 alone $(\triangle), 50 \mathrm{IU}$ of hCG alone $(\bullet)$, or $50 \mathrm{IU}$ of hCG plus $10^{2} \mathrm{ng} / \mathrm{ml}$ of IGFBP-3 $(\mathbf{\Delta})$. Data points represent the mean \pm SEM of six ovaries from six different rabbits. Values with asterisks differed significantly from values in ovaries perfused with medium alone; $* P<0.05 ; * * P<0.01 ; * * * P<0.001$. Values with daggers differed significantly from values in hCG-treated ovaries; ${ }^{\dagger} P<$ $0.05 ;{ }^{\dagger} P<0.01$.

action of IGF-I on ovarian secretion rates of Ang II-IR was dose dependent. These findings suggest that the effects of IGF-I are either exerted directly on the ovary or are mediated via an IGF-I-dependent process in rabbits, supporting the hypothesis that Ang II and IGF-I, which are thought to be important local regulators in the ovary, interact with one another in the process of follicular growth and ovulation. The existence of

Table II. Effects of Ang II on the Inhibitory Effect of IGFBP-3 in hCG-induced Ovulation

\begin{tabular}{lcc}
\hline & \multicolumn{2}{c}{ hCG-treated ovaries } \\
\cline { 2 - 3 } & $\begin{array}{c}\text { IGFBP-3 } \\
\left(10^{3} \mathrm{ng} / \mathrm{ml}\right)\end{array}$ & $\begin{array}{c}\text { IGFBP-3 }\left(10^{3} \mathrm{ng} / \mathrm{ml}\right) \\
+ \text { Ang II }(100 \mu \mathrm{g} / 2 \mathrm{~h})\end{array}$ \\
\hline No. of ovaries perfused & 6 & 6 \\
No. of ovaries ovulating & 5 & 6 \\
Ovulatory efficiency $(\%)^{*}$ & $32.4 \pm 10.4$ & $66.7 \pm 9.3^{\ddagger}$ \\
Tie of ovulation $(\mathrm{h})$ & $9.25 \pm 0.62$ & $8.88 \pm 0.42$ \\
\hline
\end{tabular}

* Percentage of mature follicles that proceeded to rupture during perfusion. ${ }^{\ddagger}$ Significantly $(P<0.05)$ compared with ovaries perfused with IGFBP-3 alone. 

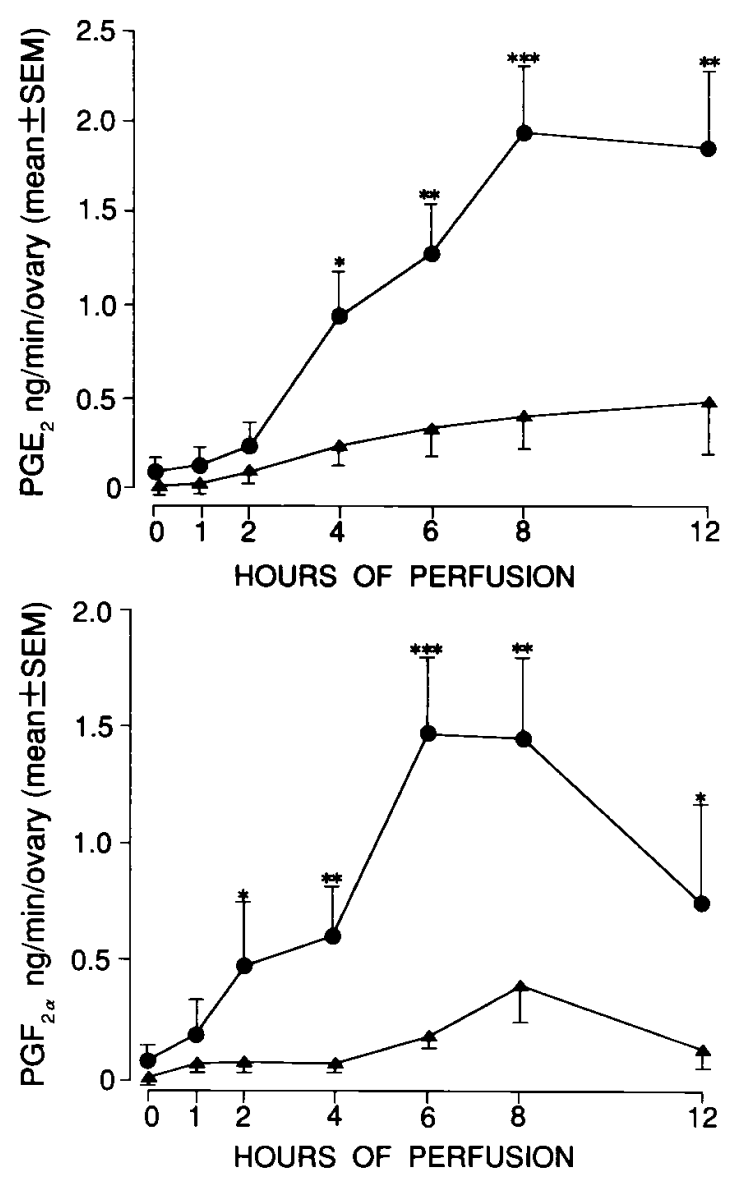

Figure 7. Effect of Ang II on the inhibitory effect of IGFBP-3 in hCG-induced $\mathrm{PG}$ production in perfused rabbit ovaries. Ovaries were perfused with $10^{3} \mathrm{ng} / \mathrm{ml}$ of IGFBP-3. $30 \mathrm{~min}$ after the onset of perfusion, $50 \mathrm{IU}$ of hCG was added to the perfusate of both ovaries. Ang II $(100 \mu \mathrm{g})$ was administered as a bolus injection of one ovary every $2 \mathrm{~h}$ for $12 \mathrm{~h}$ of perfusion $(\bullet)$, while $0.1 \mathrm{ml}$ of PBS was administered every $2 \mathrm{~h}$ in the contralateral ovary $(\boldsymbol{\Delta})$. Data points represent the mean \pm SEM of six ovaries from six different rabbits. Values with asterisks differed significantly from values in ovaries perfused with IGFBP-3 plus hCG, $* P<0.05 ; * * P<0.01 ; * * * P<0.001$.

an intraovarian IGF system complete with ligands, receptors, and binding proteins at the levels of the somatic ovarian cells suggests a variety of significant physiological effects in vivo (1, $4,5,10,12)$. To the best of our knowledge, stimulation of ovarian Ang II production by IGF-I treatment has not been reported previously. However, exogenously administered IGF-I did not induce ovulation in vitro in the absence of gonadotropin (29), despite the significant increase in ovarian secretion of Ang II-IR. This implies that components other than Ang II within the preovulatory follicular environment may also be required for follicles to rupture.

Locally produced Ang II functions as a significant autocrine or paracrine modulator in the processes leading to ovulation $(6,7,16,17,20)$. We demonstrated previously a direct effect of Ang II on the rabbit ovary, suggesting that Ang II may play a critical role in the ovulatory cascade $(7,20,30)$. The addition of saralasin, a peptide Ang II antagonist, to the perfusate blocked hCG-induced ovulation in vitro in a dose-dependent manner (20). The plasma concentration of prorenin increased almost exactly at the time of ovulation $(16,31)$, and

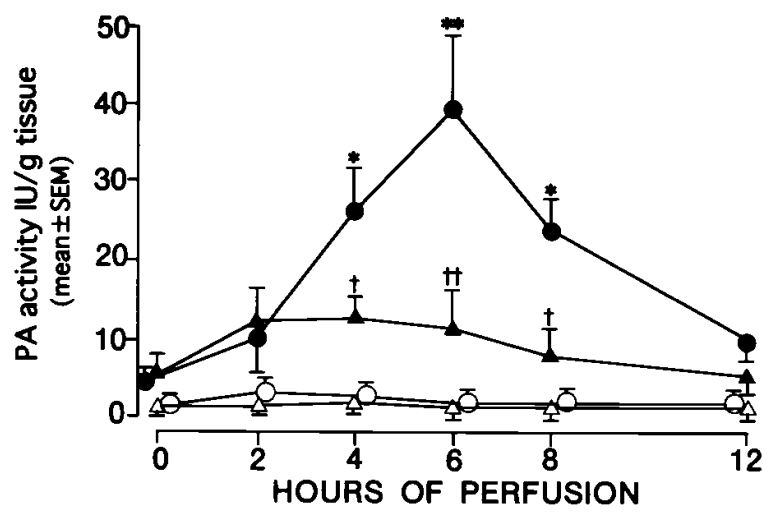

Figure 8. Effect of IGFBP-3 on IGF-I-stimulated PA activity in the follicles. Ovaries were perfused with medium alone $(\bigcirc), 10^{2} \mathrm{ng} / \mathrm{ml}$ of IGFBP-3 alone $(\triangle), 10^{2} \mathrm{ng} / \mathrm{ml}$ of IGF-I alone $(\bullet)$, or $10^{2} \mathrm{ng} / \mathrm{ml}$ of IGF-I plus $10^{2} \mathrm{ng} / \mathrm{ml}$ of IGFBP-3 $(\mathbf{\Lambda})$. Ovarian perfusion was terminated before and 2, 4, 6, 8, and $12 \mathrm{~h}$ after IGF-I or IGFBP-3 administration. Data points represent the mean \pm SEM of at least 15 follicles in three ovaries from three different rabbits. Values with asterisk differed significantly from values in ovaries perfused with medium alone; $* P<0.01 ; * * P<0.001$. Values with daggers differed significantly from values in IGF-I-treated ovaries; ${ }^{\dagger} P<0.05 ;{ }^{\dagger} P<0.01$.

gonadotropin stimulated renin activity and Ang II-IR in follicular fluids (32). In addition, exposure to hCG in vitro enhanced intrafollicular renin activity and the secretion rate of Ang II-IR in perfused rabbit ovaries $(20,30)$. In IGF-I-treated ovaries, as determined in the present study, a significant correlation was observed between follicular growth and the secretion rate of Ang II-IR in perfused rabbit ovaries, suggesting that IGF-I may enhance follicular development by stimulating ovarian production of Ang II.

The synthesis and secretion of IGFBPs are thought to play important roles in the regulation of IGF hormonal action at the target cell level at a time when the extracellular concentration of IGF-I remains constant (33-35). Depending on the circumstances, IGFBPs can either inhibit (35) or stimulate (34) the action of IGF-I on mammalian cells, but their predominant

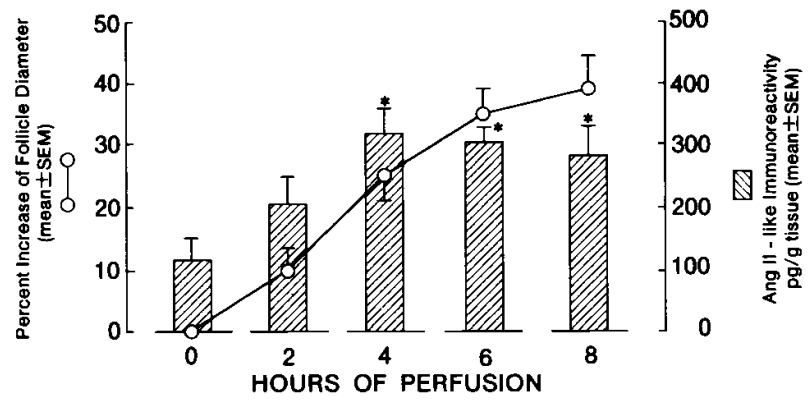

Figure 9. Effects of streptokinase on follicular growth and intrafollicular Ang II-IR content. Ovaries were perfused with 100 Units of streptokinase. Ovarian perfusion was terminated before and 2, 4, 6, and $8 \mathrm{~h}$ after exposure to streptokinase. The follicle diameter was determined at each time during perfusion and the percent increase was calculated for each follicle. The intrafollicular Ang II-IR content (pg/g tissue) was determined for each follicle. Data represent the mean \pm SEM of at least 24 follicles in six ovaries from six different rabbits. Values with asterisks differed significantly from values in unstimulated ovaries; $* P<0.05$. 
Table III. Effects of IGFBP-3 on Streptokinase-stimulated Ang II Production and Follicular Growth

\begin{tabular}{lcc}
\hline & $\begin{array}{c}\text { Streptokinase } \\
(100 \mathrm{IU})\end{array}$ & $\begin{array}{c}\text { Streptokinase }(100 \mathrm{IU}) \\
+ \text { IGFBP-3 }\left(10^{3} \mathrm{ng} / \mathrm{ml}\right)\end{array}$ \\
\hline $\begin{array}{l}\text { No. of ovaries perfused } \\
\text { No. of follicles }\end{array}$ & 6 & 6 \\
$\begin{array}{l}\text { Ang II-like immunoreactivity* } \\
\quad(\mathrm{pg} / \mathrm{g} \text { tissue) }\end{array}$ & 32 & 36 \\
Percent increase of follicle diameter & $31.5 \pm 5.4$ & $34.3 \pm 6.6$ \\
& & \\
\hline
\end{tabular}

* Intrafollicular Ang II-like immunoreactive content was determined for each follicle. ${ }^{*}$ Follicle diameters were determined before perfusion and $6 \mathrm{~h}$ after perfusion.

effect on ovarian follicular cells in vitro appears to be inhibitory $(12,13,15)$. Although this development adds a new level of complexity to the interaction with IGF-I at the cellular level, the precise biological role(s) of IGFBPs in the ovulatory process remains to be clarified. The present study demonstrated that IGFBP-3 inhibited hCG-induced ovulation in a dose-dependent manner in perfused rabbit ovaries, implying that IGFBP-3 impairs some biochemical events required for ovulation. In addition, IGFBP-3 significantly reduced the ovarian secretion rate of Ang II-IR and PGs stimulated by exposure to hCG. The present findings, using in vitro perfused rabbit ovaries, are consistent with the in vivo data obtained with the technique of ovarian intrabursal administration, showing that locally administered IGFBP-3 inhibited follicle rupture in gonadotropin-treated immature female rats (36). We found previously that exposure to hCG significantly stimulated both the tissue concentrations of IGF-I in perfused rabbit ovaries (11) and the intrafollicular IGF-I mRNA levels (20). Cotreatment with IGFBP-3 and hCG dose-dependently inhibited the stimulatory effect of hCG on ovulation, suggesting a mediatory role of endogenously produced IGF-I. Growing evidence supports the view that Ang II in ovarian RAS is the centerpiece of an intraregulatory loop involved in promoting key ovulatory events $(17,20,28,31)$. In the rabbit ovary, Ang II has been shown to induce ovulation, at least in part, by a mechanism that depends on a stimulatory effect of Ang II on PG production (7). In the present study, IGFBP-3 significantly inhibited hCG-stimulated PG production, concomitant with the blockade of ovulation. In addition, Ang II reversed the inhibitory effect of IGFBP-3 on hCG-induced ovulation and PG production. This implies that the inhibition of Ang II production by IGFBP-3 leads to the reduced levels of PGs. Alternatively, IGFBP-3 may block hCG-induced ovulation via a mechanism involving the inhibition of hCG-stimulated ovarian Ang II production.

Significant stimulation of intrafollicular PA activity in ovaries treated with IGF-I is consistent with the results of a recent study showing that IGF-I stimulated PA activity in rat astrocytes, the functions of which are related to cell proliferation, migration and differentiation during development (37). A number of growth factors, including epidermal growth factor (38), IGF-I (39) and platelet-derived growth factor (40), are known to regulate PA; the modulation of PA activity by specific growth factors varies widely depending on the cell type. PA is thought to be involved in several physiological processes within the ovary, such as cellular differentiation, follicular mat-

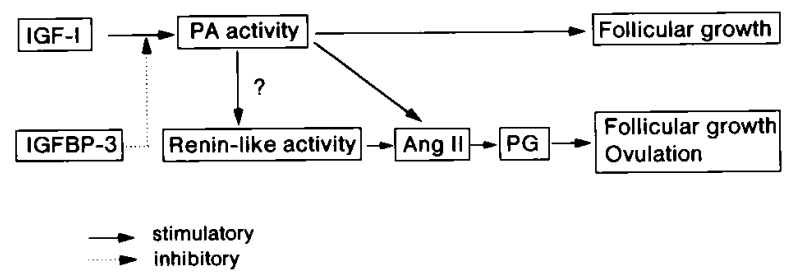

Figure 10. Proposed hypothesis of interactions between intraovarian IGF-I-IGFBPs and the renin-angiotensin system in the process of follicular development and ovulation.

uration, and ovulation $(24,28,41,42)$. The increase in intrafollicular PA activity observed in IGF-I-treated ovaries was almost identical to that observed previously in mature follicles following exposure to hCG (28). Pellicer et al. (42) have demonstrated that follicular development is impaired by inhibitors of serine proteases in the rat, suggesting that an increase in PA activity in preovulatory follicles may be of particular importance in the process of follicular development. Attention has focused recently on IGFBPs in the process of follicle rupture (36), suggesting that locally produced ovarian IGFBPs may modulate the synthesis of receptors for LH on the granulosa and theca interna cell surfaces and may also affect proteolytic enzyme activities necessary for ovulation. We found recently that IGFBP-3 contributes to the regulation of intrafollicular PA activity during follicular development and ovulation evoked by gonadotropin exposure (29). In the present study, concomitant addition of IGFBP-3 to the perfusate significantly reduced the intrafollicular PA activity stimulated by IGF-I. These findings suggest that IGF-I may enhance follicular growth by stimulating ovarian PA activity, and that IGFBP-3 may modulate the proteolytic enzyme activity required for follicle rupture.

Gonadotropin induction of follicular PA activity leads to plasmin formation, activates latent collagenase, and initiates the proteolytic enzyme changes that lead to ovulation $(24,41$, 42). Exposure to streptokinase, an exogenous PA, of in vitro perfused rabbit ovaries caused rapid composition of connective tissues and dissociation of follicular collagen fibrils, leading to follicular growth and rupture in the absence of gonadotropin (24). The present study demonstrated that streptokinase stimulated both follicular growth and the intrafollicular content of Ang II-IR in perfused rabbit ovaries. Although hCGinduced increase in Ang II-IR was significantly blocked by IGFBP-3, IGFBP-3 affected neither the production of Ang II nor follicular growth evoked by streptokinase. This implies that IGFBP-3 may block the stimulatory effects of hCG on intrafollicular PA activity by neutralizing endogenously produced IGF-I. There is ample evidence for the presence of nonrenin enzymes in other extrarenal tissues that participate in the production of Ang II from angiotensinogen (43-45). Chromatographic separation of renin-like enzymes had yielded fractions containing nonrenin neutral or acidic proteases capable of generating Ang I from angiotensinogen (46). An in vitro study has also shown that tissue PA can cleave Ang II from either tetradecapeptide renin substrate or purified human angiotensinogen (47). We speculate that serine proteases, including PA and plasmin that are produced by follicular cells after a gonadotropin surge $(48,49)$, may participate in the local regulation of Ang II and the amplification of local RAS activity in the ovary. In preovulatory follicles, the abrupt rise of Ang 
II-IR following gonadotropin surge (30) may be achieved by activation of the ovarian RAS via the PA pathway. Since the increase in the ovarian secretion rate of Ang II-IR is related to follicular development in IGF-I-treated ovaries, it is also possible that this aspect of follicular development is, to a degree, under the control of Ang II stimulated by the increase in intrafollicular PA activity.

We propose the following working model for interactions between intraovarian IGF-I-IGFBP-3 and the ovarian RAS in the process of follicular growth and ovulation (Fig. 10). A gonadotropin surge stimulates intraovarian production of IGF-I during follicular development (11). The increase in ovarian IGF-I synthesis stimulates intrafollicular PA activity. IGFBP-3 blocks the stimulatory effects of gonadotropin in the ovulatory process by neutralizing endogenously produced IGF-I, resulting in reduced intrafollicular PA activity. An increase in intrafollicular PA activity is required for the process of follicular development $(28,42)$. Intrafollicular PA activity stimulates the generation of Ang II in the preovulatory follicles by activation of prorenin to renin and/or by direct cleavage of angiotensinogen $(46,47)$. Elevated intrafollicular Ang II stimulates ovarian PG production (7), leading to follicular growth and disruption of the wall of the ovarian follicle required for ovulation. In conclusion, IGF-I enhances ovarian Ang II production and follicular growth by stimulating intrafollicular PA activity. Thus, IGF-I and Ang II may interact with one another in the mechanisms controlling follicular development and ovulation.

\section{References}

1. Adashi, E.Y., C.E. Resnick, A.J. D’Ercole, M.E. Svoboda, and J.J. Van Wyk. 1985. Insulin-like growth factors as intraovarian regulators of granulosa cell growth and function. Endocr. Rev. 6:400-420.

2. Tonetta, S.A., and G.S. DiZerega. 1989. Intragonadal regulation of follicular maturation. Endocr. Rev. 10:205-229.

3. Erickson, G.F., V.G. Garzo, and D.A. Magoffin. 1989. Insulin-like growth factor-I regulates aromatase activity in human granulosa and granulosa luteal cells. J. Clin. Endocrinol. Metab. 69:716-724.

4. Oliver, J.E., T.J. Aitman, J.F. Powell, C.A. Wilson, and R.N. Clayton. 1989. Insulin-like growth factor I gene expression in the rat ovary is confined to the granulosa cells of developing follicles. Endocrinology. 124:2671-2679.

5. Adashi, E.Y., C.E. Resnick, A. Hurwitz, E. Ricciarelli, E.R. Hernandez, and R.G. Rosenfeld. 1991. Ovarian granulosa cell-derived insulin-like growth factor binding proteins: modulatory role of follicle-stimulating hormone. Endocrinology. 128:754-760.

6. Pellicer, A., A. Palumbo, A.H. DeCherney, and F. Naftolin. 1988. Blockade of ovulation by an angiotensin antagonist. Science (Wash. DC). 240:16601661.

7. Yoshimura, Y., M. Karube, T. Oda, N. Koyama, S. Shiokawa, M. Akiba, A. Yoshinaga, and Y. Nakamura. 1993. Locally produced angiotensin II induces ovulation by stimulating prostaglandin production in in vitro perfused rabbit ovaries. Endocrinology. 133:1609-1616.

8. Mondschein, J.S., S.A. Smith, and J.M. Hammond. 1990. Production of insulin-like growth factor binding proteins (IGFBPs) by porcine granulosa cells: identification of IGFBP-2 and -3 and regulation by hormones and growth factors. Endocrinology. 127:2298-2306.

9. Davoren, J.B., A.J.W. Hsueh, and C.H. Li. 1985. Somatomedin C augments FSH-induced differentiation of cultured rat granulosa cells. Am. J. Physiol. 249:E26-E33.

10. Davoren, J.B., B.G. Kasson, C.H. Li, and A.J.W. Hsueh. 1986. Specific insulin-like growth factor (IGF) I- and II-binding sites on rat granulosa cells: relation to IGF action. Endocrinology. 119:2155-2162.

11. Yoshimura, Y., M. Iwashita, M. Karube, T. Oda, M. Akiba, S. Shiokawa, M. Ando, A. Yoshinaga, and Y. Nakamura. 1994. Growth hormone stimulates follicular development by stimulating ovarian production of insulinlike growth factor-I. Endocrinology. 135:887-894.

12. Ui, M., M. Shimonaka, S. Shimasaki, and M. Ling. 1989. An insulin-like growth factor-binding protein in ovarian follicular fluid blocks follicle-stimulating hormone-stimulated steroid production by ovarian granulosa cells. Endocrinology. 125:912-926.

13. Bicsak, T.A., M. Shimonaka, M. Malkowski, and N. Ling. 1990. Insulinlike growth factor-binding protein (IGF-BP) inhibition of granulosa cell func- tion: effect on cyclic adenosine $3^{\prime}, 5^{\prime}$-monophosphate, deoxyribonucleic acid synthesis, and comparison with the effect of an IGF-I antibody. Endocrinology. 124:2184-2189.

14. Liu, L., A. Brinkman, C. Blat, and L. Harel. 1991. IGFBP-1, an insulinlike growth factor binding protein, is a cell growth inhibitor. Biochem. Biophys. Res. Commun. 174:673-679.

15. Bicsak, T.A., N. Ling, and L.V. DePaolo. 1991. Ovarian intrabursal administration of insulin-like growth factor-binding protein inhibits follicle rupture in gonadotropin-treated immature female rats. Biol. Reprod. 44:599-603.

16. Glorioso, N., S.A. Atlas, J.H. Laragh, R. Jewelewicz, and J.E. Sealey. 1984. Prorenin in high concentrations in human ovarian follicular fluid. Science (Wash. DC). 233:1422-1424.

17. Culler, M.D., B.C. Tarlatzis, L.A. Fernandez, A.H. DeCherney, A. Negro-Vilar, and F. Naftolin. 1986. Angiotensin II-like immunoreactivity in human ovarian follicular fluid. J. Clin. Endocrinol. Metab. 62:613-615.

18. Ohkubo, H., K. Nakayama, T. Tanaka, and S. Nakanishi. 1986. Tissue distribution of rat angiotensinogen mRNA and structural analysis of its heterogeneity. J. Biol. Chem. 261:319-323.

19. Kim, S.J., M. Sinjo, A. Fukamizu, H. Miyasaki, S. Usuki, and K. Murakami. 1987. Identification of renin and renin messenger RNA sequence in rat ovary and uterus. Biochem. Biophys. Res. Commun. 142:169-175.

20. Yoshimura, Y., M. Karube, N. Koyama, S. Shiokawa, T. Nanno, and Y. Nakamura. 1992. Angiotensin II directly induces follicle rupture and oocyte maturation in the rabbit. FEBS (Fed. Eur. Biochem. Soc.) Lett. 307:305-308.

21. Yoshimura, Y., Y. Nakamura, M. Shiraki, Y. Hirota, H. Yamada, M. Ando, Y. Ubukata, and M. Suzuki. 1991. Involvement of leukotriene $\mathrm{B}_{4}$ in ovulation in the rabbit Endocrinology. 129:193-199.

22. Kobayashi, Y., K.H. Wright, R. Santulli, and E.E. Wallach. 1981. Ovulation and ovum maturation in the rabbit ovary perfused in vitro. Biol. Reprod. 24:483-490.

23. Yoshimura, Y., Y. Nakamura, T. Oda, H. Yamada, T. Nanno, Y. Ando, Y. Ubukata, and M. Suzuki. 1990. Effects of gonadotropin-releasing hormone agonists on meiotic maturation of follicle-enclosed oocytes in rabbits. Biol. Reprod. 43:1012-1018

24. Yoshimura, Y., R. Santulli, S.J. Atlas, S. Fujii, and E.E. Wallach. 1987. The effects of proteolytic enzymes on in vitro ovulation in the rabbit. Am. J. Obstet. Gynecol. 157:468-475.

25. Beadwell, C.G. 1971. Radioimmunoassay for arginine vasopressin in human plasma. J. Clin. Endocrinol. Metab. 33:254-260.

26. Morimoto, T., M. Aoyama, E. Gotoh, and H. Shionoiri. 1983. A method of radioimmunoassay of plasma angiotensin II using florisil. Folia. Endocrinol. Jap. 59:215-229.

27. Ichikawa, R., Y. Yoshimura, T. Oda, M. Shiraki, K. Maruyama, S. Kawakami, Y. Nakamura, and M. Fukushima. 1990. The effects of lipoxygenase products on progesterone and prostaglandin production by human corpora lutea. J. Clin. Endocrinol. Metab. 70:849-855.

28. Yoshimura, Y., K. Maruyama, M. Shiraki, S. Kawakami, M. Fukushima, and Y. Nakamura. 1990. Prolactin inhibits plasminogen activator activity in the preovulatory follicles. Endocrinology. 126:631-636.

29. Yoshimura, Y., S. Nagamatsu, M. Ando, M. Iwashita, T. Oda, Y. Katsumata, S. Shiokawa, and Y. Nakamura. 1996. Insulin-like growth factor binding protein-3 inhibits gonadotropin-induced ovulation, oocyte maturation, and steroidogenesis in rabbit ovary. Endocrinology. 137:438-446.

30. Yoshimura, Y., N. Koyama, M. Karube, T. Oda, M. Akiba, A. Yoshinaga, S. Shiokawa, M. Jinno, and Y. Nakamura. 1994. Gonadotropin stimulates ovarian renin-angiotensin system in the rabbit. J. Clin. Invest. 93:180-187.

31. Sealey, J.E., I. Cholst, N. Glorioso, C. Troffa, I.D. Weintraub, G. James, and J.H. Laragh. 1987. Sequential changes in plasma luteinizing hormone and plasma prorenin during the menstrual cycle. J. Clin. Endocrinol. Metab. 63:1-5.

32. Lightman, A., B.C. Tarlatzis, P.J. Rzasa, M.D. Cellular, V.J. Caride, A.F. Negro-Vilar, D. Lennard, A.H. DeCherney, and F. Naftolin. 1987. The ovarian renin-angiotensin system: renin-like activity and angiotensin II/III immunoreactivity in gonadotropin-stimulated and unstimulated human follicular fluid. Am. J. Obstet. Gynecol. 156:808-816.

33. DeVroede, M.A., L.Y.-H. Tseng, P.G. Katsoyannis, S.P. Nissey, and M.M. Rechler. 1986. Modulation of insulin-like growth factor I binding to human fibroblast monolayer cultures by insulin-like growth factor carrier proteins released to the incubation media. J. Clin. Invest. 77:602-613.

34. Elgin, R.G., W.H. Busby Jr., and D.R. Clemmons. 1987. An insulin-like growth factor (IGF) binding protein enhances the biological response to IGF-I. Proc. Natl. Acad. Sci. USA. 84:3254-3258.

35. Burch, W.M., J. Correa, J.E. Shively, and D.R. Powell. 1990. The 25kilodalton insulin-like growth factor (IGF)-binding protein inhibits both basal and IGF-I-mediated growth of chick embryo cartilage in vitro. J. Clin. Endocrinol. Metab. 70:173-180.

36. Bicsak, T.A., N. Ling, and L.V. Depaolo. 1991. Ovarian intrabursal administration of insulin-like growth factor-binding protein inhibits follicle rupture in gonadotropin-treated immature female rats. Biol. Reprod. 44:599-603.

37. Tranque, P., F. Naftolin, and R. Robbins. 1994. Differential regulation of astrocyte plasminogen activators by insulin-like growth factor-I and epidermal growth factor. Endocrinology. 134:2606-2613.

38. Stoppelli, M.P., P. Verde, G. Grimaldi, E.K. Locatille, and F. Blasi. 
1986. Increase in urokinase plasminogen activator mRNA synthesis in human carcinoma cells is a primary effect of the potent tumor-promoter phorbol myristate acetate. J. Cell Biol. 102:1235-1244.

39. Fattal, P.G., D.J. Schneider, B.E. Sobel, and J.J. Billadello. 1992. Posttranscriptional regulation of expression of plasminogen activator inhibitor type 1 mRNA by insulin and insulin-like growth factor-1. J. Biol. Chem. 267:1241212415

40. Pfeilschifter, J., R. Krempien, A. Naumann, R.G.K. Gronwald, J. Hoppe, and R. Ziegler. 1992. Differential effects of platelet-derived growth factor isoforms on plasminogen activator activity in fetal rat osteoblasts due to isoform-specific receptor functions. Endocrinology. 130:2059-2066.

41. Tsafriri, A., T.A. Bicsak, S.G. Cajander, T. Ny, and A.J.W. Hsueh. 1989. Suppression of ovulation rate by antibodies to tissue-type plasminogen activator and $\alpha_{2}$-antiplasmin. Endocrinology. 124:415-421.

42. Pellicer, A., A. Lightman, A. Ariza, A.H. DeCherney, F. Naftolin, and B.A. Littlefield. 1988. Follicular development is impaired by inhibitors of serine proteases in the rat. Am. J. Obstet. Gynecol. 158:670-676.

43. Dzau, V.J., A. Brenner, and N.L. Emmett. 1982. Evidence for renin in rat brain: differentiation from other renin-like enzymes. Am. J. Physiol. 242:
E292-E297.

44. Husain, A., R. Smeby, D. Wiek, V.J. Dzau, and F.M. Bumpus. 1984 Biochemical and immunological properties of dog brain isorenin. Endocrinology. 114:2210-2215

45. Dzau, V.J., D. Gonzalez, K. Ellison, S. Churchill, and N.L. Emmett 1987. Characterization of purified rabbit uterine renin: influence of pregnancy on uterine inactive renin. Endocrinology. 120:358-364.

46. Dzau, V.J. 1984. Vascular renin-angiotensin: a possible autocrine or paracrine system in control of vascular function. J. Cardiovasc. Pharmacol. 6(suppl):S377-S382

47. Tsang, S.S., J. Loscalzo, and V.J. Dzau. 1989. Tissue plasminogen activator activates renin angiotensin in vitro. J. Vasc. Med. Biol. 1:67-74.

48. Canipari, R., and S. Strickland. 1985. Plasminogen activator in the ovary. Production and gonadotropin regulation of the enzyme in granulosa and theca cells. J. Biol. Chem. 260:5121-5125.

49. Yoshimura, Y., M. Jinno, T. Oda, S. Shiokawa, A. Yoshinaga, I. Hanyu, M. Akiba, and Y. Nakamura. 1994. Prolactin inhibits ovulation by reducing ovarian plasmin generation. Biol. Reprod. 50:1223-1230. 